\begin{tabular}{|c|c|c|}
\hline $\begin{array}{l}\text { Asian Journal of Pharmaceutical Research } \\
\text { and Development } \\
\text { (An International Peer-Reviewed Journal of Pharmaceutical Research and Develooment }\end{array}$ & & \\
\hline 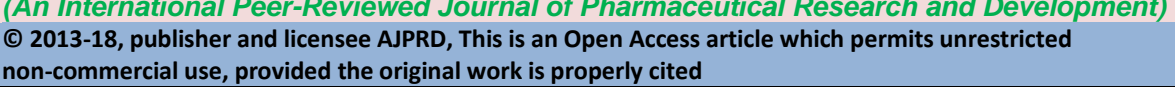 & $\begin{array}{l}\mathbf{R} \\
\mathbf{D}\end{array}$ & \\
\hline
\end{tabular}

\title{
CALCIUM SALT OF CARBOXYMETHYLED AEGLE MARMELOS (BAEL FRUIT) GUM: A NOVEL SUPERDISINTEGRANT FOR FAST DISINTEGRATING TABLETS.
}

\author{
Dev Dhruv*, Rai Diksha, Prasad D. N. \\ Shivalik College of Pharmacy, Nangal, Punjab, India
}

\begin{abstract}
The present study was carried out for the preparation of modified Aegle marmelos gum as natural superdisintegrant and assessed it on various parameters for preparing fast dissolving dosage form. The extracted gum from Aegle marmelos fruit is chemically modified by carrying out its carboxymethylation and further complexed with Calcium chloride. Therefore, the natural Superdisintegrant prepared from Aegle marmelos gum followed swelling and wetting mechanism for disintegration of the dosage form. The change in the functional groups of the extracted gum, carboxymethyled gum and the calcium complexed gum was studied by FT-IR spectrophotometer and DSC studies. Pre-compression parameters of the tablet such as Swelling index, bulk density, tapped density, carr's index, angle of repose and hausner's ratio were determined. Dummy tablets containing calcium complexed Aegle marmelos gum were formulated to check the disintegrating efficiency of the tablets. The disintegrating properties of calcium complexed Aegle marmelos gum as superdisintegrant was compared with the marketed Superdisintegrant Sodium starch glycolate. The comparison between both the formulations containing different superdisintegrants in various batches was done to check the disintegrating efficiency of the modified Aegle marmelos gum as superdisintegrant. The disintegrating time for calcium complexed Aegle marmelos gum was observed to be $1 \mathrm{~min} \pm 2 \mathrm{sec}$ to $1 \mathrm{~min} \pm 5 \mathrm{sec}$ showing good disintegrating properties. The present study may serve as a prototype approach for formulation and development of novel superdisintegrant from various natural gums.
\end{abstract}

Key words: Aegle marmelos gum, Sodium Starch glycolate, modified gum, Superdisintegrant.

Article Info: Received 10 July, 2018;

Review Completed 11 Aug 2018;

Accepted 16 Aug 2018

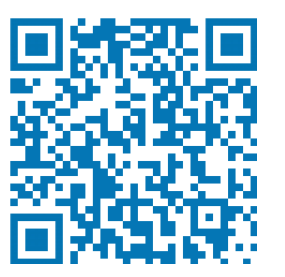

Cite this article as:

Dev Dhruv, Calcium Salt of Carboxymethyled Aegle marmelos (Bael fruit) gum: A novel Superdisintegrant for Fast Disintegrating tablets, Asian Journal of Pharmaceutical research and Development.2018;6 (4): 67-72

\section{DOI: http://dx.doi.org/10.22270/ajprd.v6.i4.384}

*Address for Correspondence

Dhruv Dev, Shivalik College of Pharmacy, Nangal, Punjab, India

\section{INTRODUCTION}

$\mathrm{S}$ ome of the major ingredients are encapsulated into the tablet formulation which helps to break up the tablet or capsule into smaller fragments called as 'slugs' and thus are named as 'Superdisintegrants' (1). They works in the presence of aqueous environment. This helps in the fast release of the drug from the tablet or capsule. Superdisintegrants enhances the penetration of moisture and further the tablet matrix disperses. The mechanism behinds the disintegration is just the swelling of the superdisintegrant when it comes in contact with water and further it hydrates, and produces disruption in tablet $^{(2)}$. This helps in rapid release of drug from the tablet. For the disintegration, this is necessary for the disintegrant, to interact completely with water ${ }^{(3)}$.Therefore, the present study deals with a novel idea of preparing superdisintegrant from Aegle marmelos (Bael fruit) gum. Aegle marmelos (Indian Bael) fruit contains a gummy material containing highly branched nature of Terminal units of Galactose, Arabinose, Rhamnose and Galactutronic acid ${ }^{(4)}$. The carboxylic nature of the gum is responsible for the disintegrating activity. Aegle marmelos is used as antifertility agent, to cure diabetes and cholesterol levels. It has anti-inflammatory, analgesic and antimicrobial properties.Carbohydrates are the main chemical constituent present in Aegle marmelos 
gum which is modified under chemical reactions, providing it disintegrating properties. The Aegle marmelos gum is carboxymethyled and further complexed with calcium chloride that helps to change its properties for disintegration and finally be called as a "Natural Superdisintegrant". This novel idea of using the natural superdisintegrant is helpful in increasing rate of disintegration by rapid drug release. Moreover, rate of drug absorption as well as bioavailability also enhances. Some of the known natural superdisintegrants contains Isapghula Husk Mucilage (Plantago ovata) Aloe Vera, Guar gum, Lepidiumsativum mucilage, Hibiscus Rosa sinensis and Fenugreek fruit mucilage whereas synthetic superdisintegrants consists of Cross povidone, Modified cellulose, Resin, Cross linked cellulose, Cross linked starch, Crosslinked polyvinylpyrrolidone, Cross linked alginic acid and Cross carmellose sodium ${ }^{(5,6)}$

\section{Materials and Method:}

Aegle Marmelos fruit as a gift sample from Shivalik college of Pharmacy, Nangal. Monochloroacetic acid, Sodium chloride and Calcium chloride were obtained from Thermo Fischer Scientific India, Pvt. Ltd., Mumbai. Alcohol and isopropanol were obtained from Avantor Performance Materials India Ltd., Gujrat. Eriochrome black-T and EDTA were obtained from Himedia Laboratories Pvt. Ltd., Mumbai.

\section{PREPARATION OF SUPERDISINTEGRANT FROM AEGLE MARMELOS GUM}

\section{Extraction of Aegle marmelos gum}

Extraction of the gum from the fruit of A. marmelos was done by crushing the fruit of A. Marmelos in mortar pestle. The crushed material was then transferred to the $1000 \mathrm{ml}$ beaker and boiled in $500 \mathrm{ml}$ of distilled water for 5-6 hrs. After complete boiling of the crude material, filtered using a muslin cloth. The filtrate was the concentrated by boiling for 2-3 hrs using water bath. The concentrate was then cooled and alcohol was added till

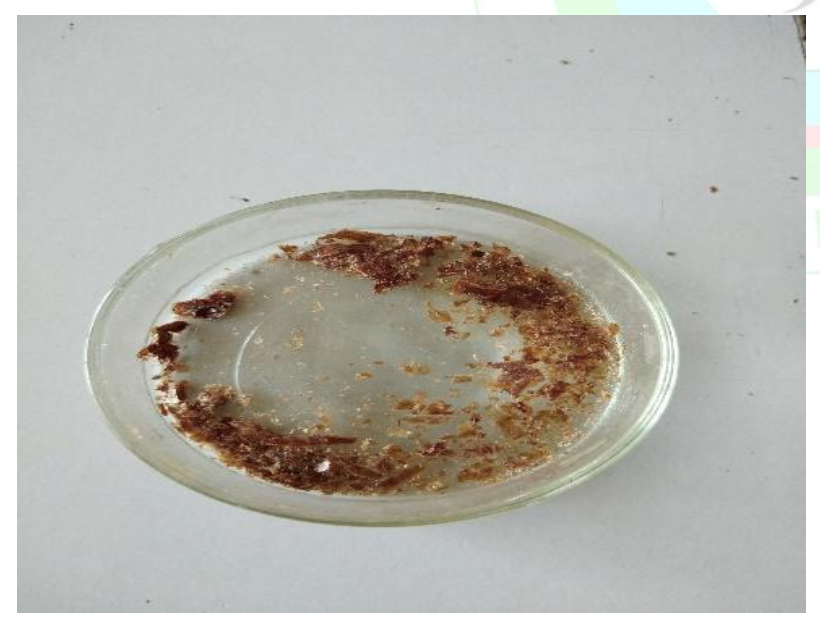

Fig. 1: Carboxymethyled Aegle marmelos gum

\section{CHARACTERIZATION OF AEGLE MARMELOS GUM}

The simple extracted gum and modified gum was characterized for following parameters: the formation of precipitates takes place. The precipitates were separated out using vacuum filtration apparatus. The precipitates were then dried under the sunlight. The resulted precipitates is the resultant Aegle. marmelos gum.

\section{Preparation of Carboxymethyled Aegle marmelos $\operatorname{gum}(\mathrm{CMAM})^{(7)}$}

CMAM was synthesized from Aegle marmelos gum. Briefly, an aqueous dispersion of Aegle Marmelos gum $(1.25 \%, \mathrm{w} / \mathrm{v})$ in ice cold sodium hydroxide $(45 \%, \mathrm{w} / \mathrm{w})$ was prepared by stirring for $30 \mathrm{~min}$. To this $25 \mathrm{~mL}$ of aqueous solution of monochloroacetic acid $(45 \%, \mathrm{w} / \mathrm{v})$ was added with constant stirring. The reaction mixture was then heated to $70{ }^{\circ} \mathrm{C}$ under constant stirring for 30 min, cooled and suspended into $(80 \%$, v/v) methanol. Precipitates of CMAM so formed were filtered and neutralized with glacial acetic acid, followed by washing with $3 \times 60 \mathrm{~mL}$ portions of methanol $(80 \%$, v/v), filtration and drying in an oven at $40{ }^{\circ} \mathrm{C}$.

\section{Calcium complexation of the Carboxymethyled Aegle marmelos gum (CMAM) ${ }^{(8)}$}

The calcium cross linked gum derivatives were prepared by reacting the respective derivative with calcium chloride. $2.5 \mathrm{~g}$ of Carboxymethyled gum was dissolved in $50 \mathrm{ml}$ of water. Calcium chloride $(5 \%$, w/v, $50 \mathrm{ml})$ solution in water was added drop wise to the gum solution $(5 \%, \mathrm{w} / \mathrm{v}, 50 \mathrm{ml})$ with constant stirring. IPA (50 $\mathrm{ml}$ ) was added drop wise to thegum-calcium chloride solution mixture with stirring to obtainthick, uniform and gelatinous precipitates. These precipitates were repeatedly washed with distilled water to remove unreacted calciumand/or gum. The washing was stopped when the filtrate didnot yield red color from blue color after adding it to standardmagnesium-EDTA complex solution containing Eriochrome blackT indicator solution. These washed precipitates were freeze driedand then passed through \#80 sieve.

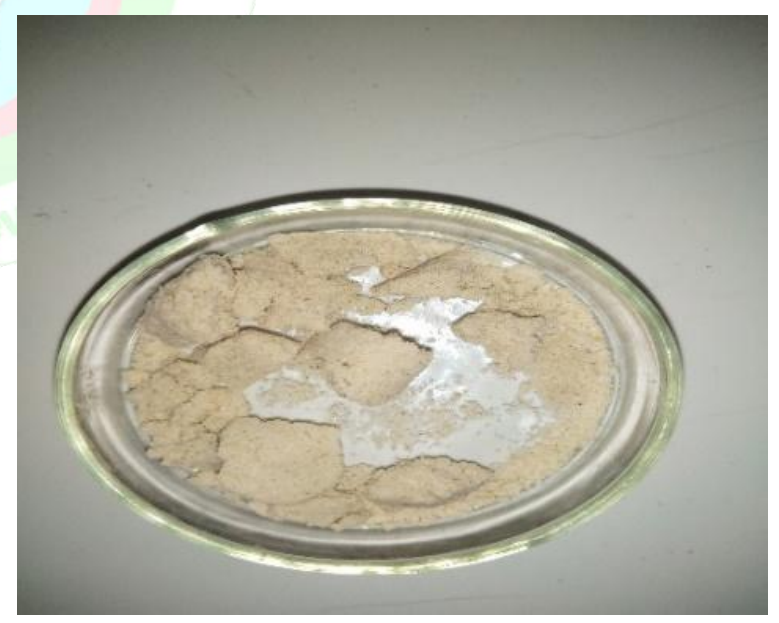

Fig. 2: Calcium complexed Aegle marmelos gum

Melting point: Melting point of pure extract of Aegle marmelos gum was observed to be $91{ }^{\circ} \mathrm{C}$ to $93^{\circ} \mathrm{C}$.

Swelling index: Swelling index is defined as the amount of water absorbed by the gum when placed in water for a predetermined time. It gives the percent of weight gain 
by the gum after absorbing water ${ }^{(9,10)}$. Swelling index is calculated from following equation:

Swelling index $=$ Final weight of the gum-Initial weight of the gum $\times 100$ Initial weight of the gum

Swelling index of the Aegle marmelos gum was found to be $\mathbf{9 2 . 8 5 \%}$. It reveals Aegle marmelos gum has good swelling properties.

\section{FT-IR Studies}

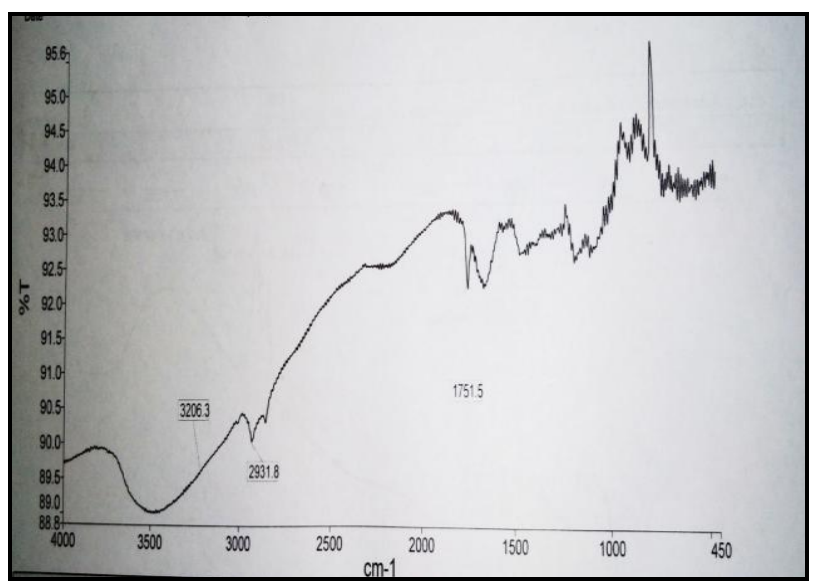

Fig. 3: FT-IR spectra for pure extracted gum from Aegle Marmelos.

Upon carboxymethylation of the gum, the property of the gum was modified by adding a methyl group. The carboxymethylation using monochloroacetic acid and $\mathrm{NaOH}$ helps to change the functional groups present in the gum. These modifications add up a methyl group to the carbohydrate group $\left(\mathrm{COO}^{-}\right)$that changes the property of the gum. As the methyl group $\left(-\mathrm{CH}_{3}\right)$ was introduced in the gum, the property of the gum becomes completely hydrophilic in nature and thus it becomes $\mathrm{COO}^{-} \mathrm{CH}-$. After modifying the carbohydrate group to carboxymethyled group, the peak shifts to $2924.28 \mathrm{~cm}^{-1}$ showing presence of methyl group. This hydrophilic nature of the gum helps in the rapid dissolution of the formulation inside the gastric fluid. This modification becomes an effective way for Aegle marmelos gum to acts as aSuperdisintegrant.The carboxymethylation reaction is followed by the following mechanism:

$$
\mathrm{COOH}+\mathrm{CH}_{3}=\mathrm{COOCH}-
$$

(Carboxylic acid) (Methyl group) (Carboxymethyled product)

After adding a methyl group to the extracted gum and enhancing its hydrophilic property, it was further complexed with $\mathrm{Ca}^{2+}$ ion so as to increasing its swelling property. To enhance this property of the carboxymethyled gum $\left(\mathrm{COO}^{-} \mathrm{CH}-\right)$, it was reacted with Calcium chloride. In this way the $-\mathrm{CH}$ - group was replaced by $\mathrm{Ca}^{2+}$ to form $\mathrm{COO}^{-} \mathrm{Ca}^{2+}$. This results in shift in the IR peak towards carbonyl group i.e, $\mathrm{C}-\mathrm{OH}$ group at $1078.24 \mathrm{~cm}^{-1}$ along with the presence of carboxylic peak at $3448.01 \mathrm{~cm}^{-1}$. The precipitates obtained after complexing with calcium chloride were observed to be somewhat porous in structure. The presence of the pores helps in enhancing the swelling property of the gum that acts as superdisintegrant. Therefore, the formulation absorbs the fluid, swells and disintegrates rapidly.Calcium complexation of the gum follows the following mechanism:
$\mathrm{Ca}^{2}+\mathrm{COO}^{-} \mathrm{CH}_{3}=\mathrm{COO}^{-} \mathrm{Ca}^{2+}$

FT-IR studies reveals characteristic bands for pure Aegle marmelos gum. The main chemical constituent of gummy material in Aegle marmelos fruit is carbohydrates and which is required for the modification of the gum. Modification enhances the property of the gum which is required for the disintegration purpose. Infrared spectra gives peak for carboxylic acid at 3600$2500 \mathrm{~cm}^{-1}$. Thus, the FT-IR spectra for pure Aegle marmelos gum shows carboxylic acid peak at $2931 \mathrm{~cm}^{-1}$ which implies presence of carbohydrates in the gum.

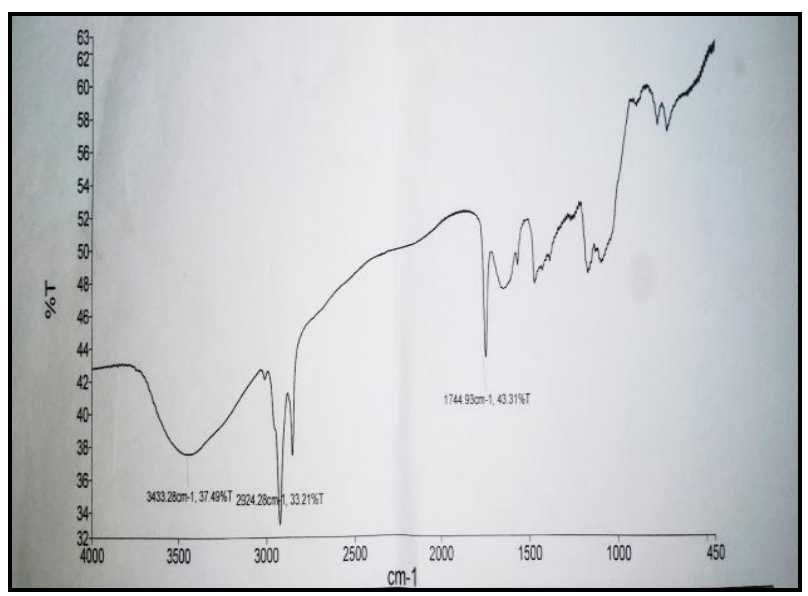

ig. 4: FT-IR spectra for Carboxymethyled Aegle marmelos gum

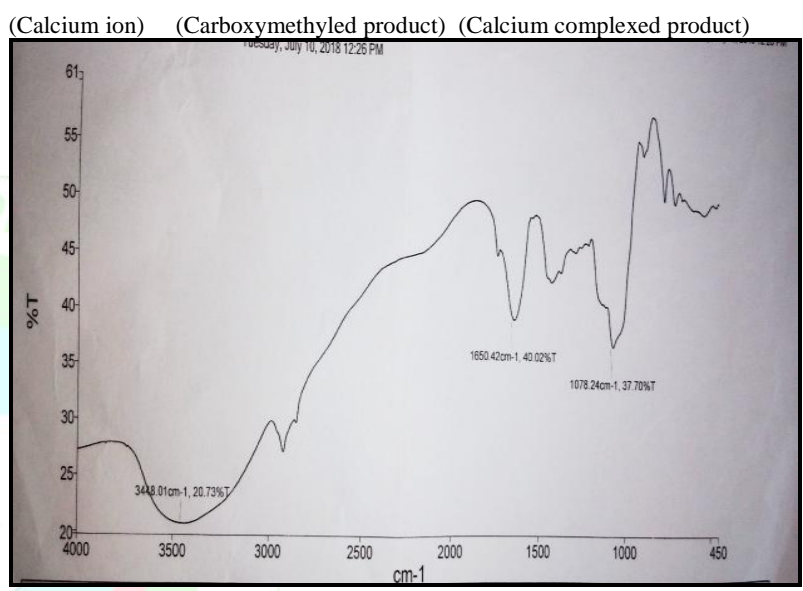

Fig. 5: FT-IR spectra for calcium complexed modified Aegle marmelos gum

DSC studies:

DSC studies reveals melting point for pure Aegle marmelos gum. The endothermic peak is observed to be at $92.59^{\circ} \mathrm{C}$. After modifications of the Aegle marmelos gum under certain chemical reactions, the peaks get shift.

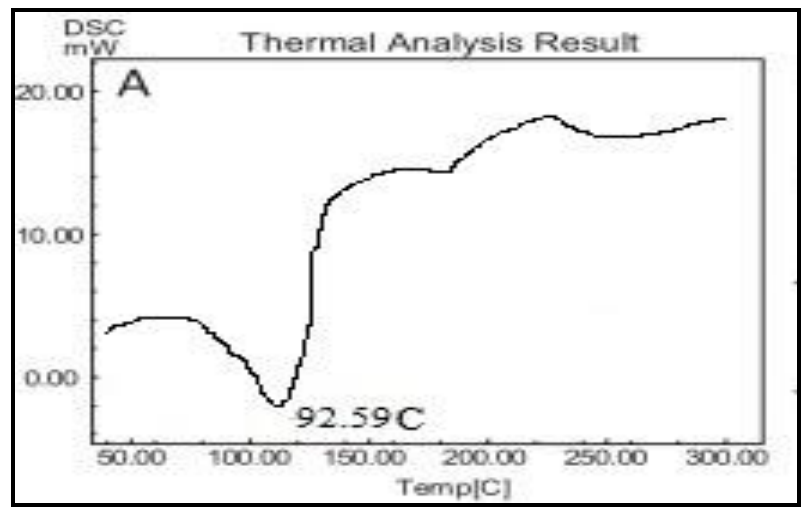

Fig. 6: DSC thermogram of Pure Aegle Marmelos gum 
Figure 6 showed that upon carboxymethylation of the Aegle marmelos gum, a sharp endothermic peak at $85.81^{\circ} \mathrm{C}$ was observed along with a small exothermic peak was also observed at $173.58^{\circ} \mathrm{C}$. The shift in the endothermic peak and variation in the heat flow provided more proof on the insertion of carboxymethyl group which provides hydrophilic properties to the gum.

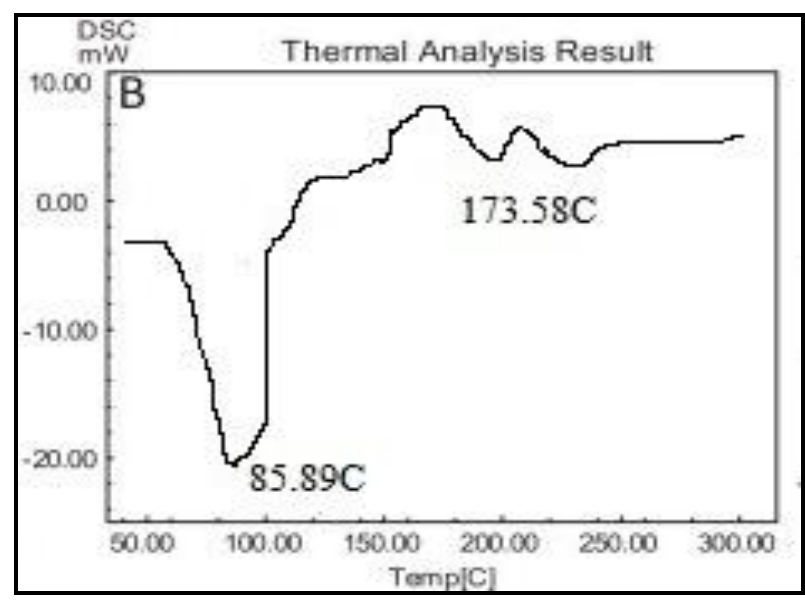

Fig. 7: DSC thermogram of Carboxymethyled Aegle marmelos gum

Figure 7 showed Calcium complexation of the carboxymethyled Aegle Marmelos gum shifts the endothermic peak towards $80.12^{\circ} \mathrm{C}$ alongwith the exothermic peak towards $285.89^{\circ} \mathrm{C}$ which reveal the alteration in the internal arrangement. From the above results of DSC, shift in the peaks reveals insertion of carbonyl group giving swelling properties to the gum so that it can easily disintegrate the formulation. ${ }^{(11,12)}$

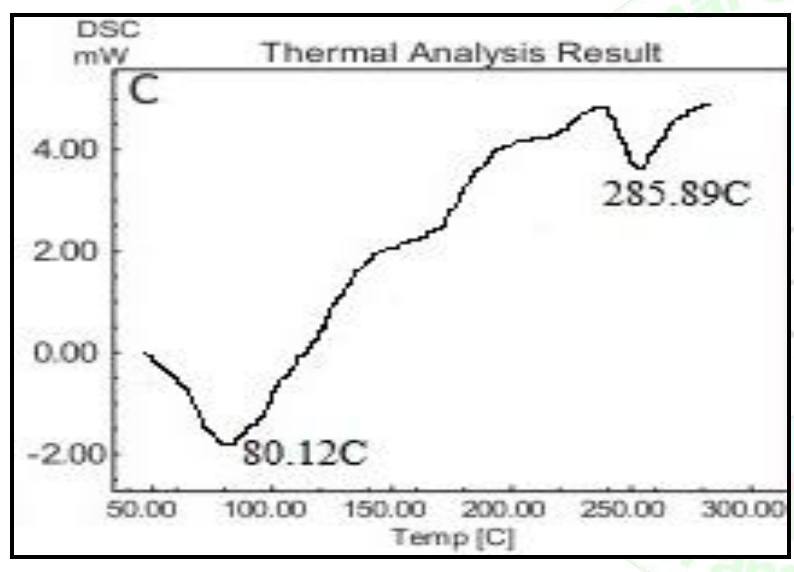

Fig. 8: DSC thermogram of Calcium complex Modified Aegle marmelos gum

Formulation of Dummy tablet Containing Aegle Marmelos Gum as Natural Superdiintegrant:

Pre-compression parameters:

Bulk density: Bulk density is defined as the total mass of the powder to the total bulk of the powder. It is

Table 1: Various pre compression parameters for superdisintegrant

\begin{tabular}{|l|l|l|l|l|l|}
\hline S.No. & $\begin{array}{l}\text { Bulk } \\
\text { density }\end{array}$ & $\begin{array}{l}\text { Tapped } \\
\text { density }\end{array}$ & $\begin{array}{l}\text { Carr's } \\
\text { index }\end{array}$ & $\begin{array}{l}\text { Angle of } \\
\text { repose }\end{array}$ & $\begin{array}{l}\text { Hausner's } \\
\text { ratio }\end{array}$ \\
\hline 1. & 0.41 & 0.46 & 22.12 & 25.74 & 1.30 \\
\hline 2. & 0.38 & 0.53 & 25.66 & 29.36 & 1.10 \\
\hline 3. & 0.40 & 0.60 & 18.43 & 35.12 & 1.20 \\
\hline 4. & 0.35 & 0.55 & 23.56 & 38.17 & 1.40 \\
\hline 5. & 0.45 & 0.65 & 15.67 & 33.65 & 1.10 \\
\hline
\end{tabular}

indicative of the packing of particles and as such is greatly influenced by the size of granules. Loose bulk density of Tablets was determined by pouring gently $2 \mathrm{~g}$ of the powder blend from each formula through a glass funnel into $10 \mathrm{ml}$ measuring cylinder. The volume occupied by the samples were noted. Loose bulk density was expressed in $(\mathrm{g} / \mathrm{ml})$ and calculated by using following formula.

\section{Bulk density $=$ mass $/$ bulk volume}

Bulk density was calculated to be $\mathbf{0 . 3 5}-\mathbf{0 . 4 5} \mathbf{g m} / \mathbf{c m}^{3}$ indicating good flow properties.

\section{Tapped density:}

Tapped density is defined as the total mass of the powder to the tapped volume of the powder. It was determined by pouring gently $2 \mathrm{~g}$ of the powder blend from each formula through a glass funnel into $10 \mathrm{ml}$ measuring cylinder. The cylinder was tapped gently on to a hard surface from the height of 2 inches at second interval until a constant volume was obtained. Volume occupied by the sample after tapping was noted. Tapped density was expressed in $(\mathrm{g} / \mathrm{ml})$ and calculated by using following formula. Tapped density was calculated to be 0.45 - $0.65 \mathbf{~ g m} / \mathbf{c m}^{3}$ indicating good flow properties ${ }^{(13)}$

Carr's index (compressibility index): Carr's index is defined as the ratio of bulk density to tapped density.

\section{[(Tapped density - Bulk Density) / Tapped Density] $\times$ 100}

Carr's index was observed to be in the range of 15.8$\mathbf{2 5 . 4 0} \%$ indicating the powder blend have the required flow property for compression which is suitable for content uniformity and less weight variation in final tablets.

Hausner's ratio: It is calculated as Tapped density/bulk density. Hausner's ratio $<1.25$ indicates good flow properties whereas $>1.5$ indicates poor flowability. Hausner's ratio was calculated to be 1.20-1.40 indicating good flowability.

Angle of Repose: It is defined as the maximum angle possible between the surface of a pile of powder and the horizontal plane; it was measured by pouring the weighed powder mixture into the funnel which was fixed to stand at a definite height (h).

$$
\theta=\tan ^{-1} h / r
$$

The values calculated for angle of repose were found to be in the range of $\mathbf{2 5 . 7 4}^{\mathbf{0}}$ to $38.82^{0}$ indicating good flow properties. $^{(14)}$ 


\section{FORMULATION OF FAST DISINTEGRATING TABLETS}

Dummy FDT's were formulated containing calcium complexed Aegle Marmelos gum as natural superdisintegrant and were compared to the synthetic superdisintegrant starch glycolate containing tablet for disintegration time in F1 to F5 formulations ${ }^{(15)}$. The concentration of the gum was varied in each batch such as $2.5 \mathrm{mg}, 5 \mathrm{mg}, 7.5 \mathrm{mg} 10 \mathrm{mg}$ and $12.5 \mathrm{mg}$. The effect of the increasing amount of the superdisintegrant was evaluated by comparing the disintegration time of the tablet.

Table 2: Formulation of dummy Fast disintegrating tablets using modified gum as superdisintegrant

\begin{tabular}{|c|c|c|c|c|c|}
\hline Formulation code & MCC (mg) & Lactose (mg) & $\begin{array}{l}\text { Calcium complexed Aegle } \\
\text { Marmelos gum (mg) }\end{array}$ & $\begin{array}{l}\text { Magnesium } \\
\text { stearate }\end{array}$ & Talc (mg) \\
\hline F1 & 100 & 43.5 & 2.5 & 2 & 2 \\
\hline F2 & 100 & 41 & 5 & 2 & 2 \\
\hline F3 & 100 & 38.5 & 7.5 & 2 & 2 \\
\hline F4 & 100 & 36 & 10 & 2 & 2 \\
\hline F5 & 100 & 33.5 & 12.5 & 2 & 2 \\
\hline
\end{tabular}

Table 3: Formulation of dummy tablet using Sodium starch glycolate as superdisintegrant

\begin{tabular}{|c|c|c|c|c|c|}
\hline Formulation code & MCC(mg) & Lactose (mg) & $\begin{array}{l}\text { Sodium starch glycolate } \\
(\mathbf{m g})\end{array}$ & $\begin{array}{l}\text { Magnesium } \\
\text { stearate (mg) }\end{array}$ & Talc (mg) \\
\hline F1 & 100 & 43.5 & 2.5 & 2 & 2 \\
\hline F2 & 100 & 41 & 5 & 2 & 2 \\
\hline F3 & 100 & 38.5 & 7.5 & 2 & 2 \\
\hline F4 & 100 & 36 & 10 & 2 & 2 \\
\hline F5 & 100 & 33.5 & 12.5 & 2 & 2 \\
\hline
\end{tabular}

Table 4: Evaluation of the Tablets Containing Different Superdisintegrant for Their Disintegration Time

\begin{tabular}{|l|c|c|}
\hline Formulation No. & Calcium complexed Aegle Marmelos gum & Sodium starch glycolate \\
\hline F1 & $45 \pm 3 s$ & $47 \pm 2 s$ \\
\hline F2 & $44 \pm 5 s$ & $45 \pm 4 s$ \\
\hline F3 & $39 \pm 2 s$ & $42 \pm 6 s$ \\
\hline F4 & $41 \pm 3 s$ & $44 \pm 3 s$ \\
\hline F5 & $36 \pm 2 s$ & $39 \pm 3 s$ \\
\hline
\end{tabular}

\section{CONCLUSION}

The present investigation revealed high super disintegrating potential of modified Aegle Marmelos gum. The fast disintegrating tablets prepared from calcium complexed Aegle marmelos gum (12.5\%) in F5 formulation showed faster disintegration of the tablet as compared to the synthetic superdisintegrant(sodium starch glycolate). The mechanism behind the rapid disintegration of tablet by calcium complexed Aegle marmelos gum is the modification of the gum by the chemical reactions so as to enhance the disintegration properties of the gum. The carboxymethylation of the

\section{REFERENCES}

1. Gohel MC, Parikh RK, Brahmbhath BK, Shah AR. Preparation and assessment of Novel co-processed superdisintegrant containing cross povidone and sodium starch glycolate: A technical note. AAPS Pharm Sci Tech. 2007; 8(1): 1-6.
Aegle marmelos gum provides hydrophilicity to the gum so that it can easily disintegrate in the environmental fluid. Further, the carboxymethyled gum was complexed with $\mathrm{Ca}^{2+}$ that forms intra or inter cross linked bridges in calcium complexed gum for water transporting system even when aqueous channels in the fast disintegrating tablets were blocked. Overall, the findings pointed calcium complexed Aegle marmelos gum could be a better superdisintegrant that provides FDT's with good mechanical strength and lowest disintegration time. Thus, this superdisintegrant could be considered useful in near future for the formulation development of fast disintegrating tablets.

2. Chougule D, Ghodke D, Shah RR, Ghaste R. Fast dissolving Tablets: An overview. Asian Journal of Pharmaceutics. 2010: 312-322.

3. Mangal M, Thakral S, Goswami M, Ghai P. Superdisintegrants: An updated review. International 
Journal of Pharmacy and Pharmaceutical Science Research. 2012; 2(2): 26-35.

4. Tuticorin R, Govindachari, Manakkal S, Premila. Some Alkaloids from Aegle Marmelos Phytochemistry. 1987; 22(3) : 755-757.

5. Mohanachandra, Sindhumol PG, Kiran TS, Superdisintegrant: An Overview. International Journal of Pharmaceutical Sciences. 2011;6 (1): 1-22.

6. Rawat Shilpi, Derle DV, Sulbha R, Pramod R, Balasaheb S. Superdisintegrants: An Overview.World Journal of Pharmacy and Pharmaceutical Sciences. 2014; 3(5) : 263-278.

7. Ahuja Munish, Singh Seema, Kumar Ashok. Evaluation of Carboxymethyl Gellan Gum as Mucoadhesive Polymer. International Journal of Biological Macromolecules. 2013; 53: 114-121.

8. Rai Ram Parshu, Tiwari AK, Rana Vikas. Superior Superdisintegrant properties of Calcium cross linked Cassia Fistula gum derivatives of Fast Dissolving Tablets. Carbohydrate Polymers.2012; 87: 1098-1104.

9. Patil C, Das S. Paper effect of various superdisintegrants on the drug release profile of disintegration time on Lamotrigine orally disintegrating Tablets. African Journal of Pharmacy and Pharmacology. 2011; 5(1): 76-82.

10. Kumar Uday M, Babu Kishore M, Design and Evaluation of Fast disintegrating tablet containing
Diclofenac sodium using Natural Superdisintegrant. Asian Pac J Trop Biomed. 2014; 4(1); 329-334.

11. Setia A, Kumar R. Microwave Assisted synthesis and optimization of Aegle Marmelos-g-polyacrylamide: Release Kinetics Studies. International Journal of Biological Macromolecules. 2014; 65: 462-470.

12. Immadi HP, Kala SLJ, Srinivasa RK, Manikiran SS, Rama Rao N. Comparative study of Natural and Synthetic Superdisintegrants in the Formulation of Orally Fast Disintegrating Tablets of Levofloxacin as Model drug. International Journal of Pharmacy and Pharmaceutical Research. 2017; 10(2): 121-138.

13. Jadhav D, Kharat R, Jhadav S, Patil MK. Design and evaluation of Sustained Release Matrix tablet of Propranolol hydrochloride. Indo-America Journal of Pharmaceutical Research. 2015: 1109-1117.

14. Shahanoor Momin, Shadab Khan, DM Ghadage, AV Yadav, Amit Wagh. Formulation and Evaluation of Bilayer tablets of Propranolol hydrochloride. Journal of Drug Delivery and Therapeutics. 2017; 7(20); 5057.

15. Rajeshvar V, M Venkata Ramana. Formulation and Evaluation of Orodispersible Rovustatin tablets: A Comparative study on Natural and Synthetic Superdisintegrants. International Journal of Pharmacy. 2016; 7(6): 39-43 